\title{
Cumulative incidence and changes in the prevalence of vertebral fractures in a rural Japanese community: a 10-year follow-up of the Miyama cohort
}

\author{
Noriko Yoshimura $\cdot$ Hirorfumi Kinoshita \\ Hiroyuki Oka • Shigeyuki Muraki • Akihiko Mabuchi • \\ Hiroshi Kawaguchi • Kozo Nakamura
}

Received: 28 April 2006 / Accepted: 17 July 2006 / Published online: 27 September 2006

(C) International Osteoporosis Foundation and National Osteoporosis Foundation 2006

\begin{abstract}
Introduction The objective of this study was to clarify secular changes in the prevalence and cumulative incidence of vertebral fractures (VFx) among the general inhabitants of Miyama, a rural Japanese community.

Methods A cohort of 1,543 inhabitants aged 40-79 years was established using resident registration in 1989. Of these, 400 participants were selected and divided into four age strata, each containing 50 men and 50 women. Participants completed a self-administered questionnaire and anthropometric measurements were taken. In 1990, baseline radiographic examinations of the thoracolumbar spine in anteroposterior and lateral views were performed. Radiographic examinations of the same sites were performed on the same participants in 2000. All VFx were
\end{abstract}

\author{
N. Yoshimura $\cdot$ H. Oka \\ Department of Joint Disease Research, 22nd Century Medical \\ and Research Center, Graduate School of Medicine, \\ University of Tokyo, \\ Tokyo, Japan \\ H. Kinoshita \\ Department of Orthopaedic Surgery, \\ Wakayama Medical University Kihoku Hospital, \\ Wakayama, Japan \\ S. Muraki $\cdot$ A. Mabuchi \\ Department of Clinical Motor System Medicine, 22nd Century \\ Medical and Research Center, Graduate School of Medicine, \\ University of Tokyo, Tokyo, Japan \\ H. Kawaguchi $\cdot$ K. Nakamura \\ Department of Orthopaedic Surgery, \\ Faculty of Medicine, University of Tokyo, \\ Tokyo, Japan \\ N. Yoshimura $(\bowtie)$ \\ 7-3-1 Hongo, Bunkyo-ku, \\ Tokyo 113-8655, Japan \\ e-mail: yoshimuran-ort@h.u-tokyo.ac.jp
}

diagnosed by the same experienced orthopedic surgeon. Evaluation of radiographic surveys after 10 years was completed for 287 of the 400 participants (132 men, 155 women; $71.8 \%$ ).

Results The prevalences of VFx at follow-up in 2000 for subjects in their $50 \mathrm{~s}, 60 \mathrm{~s}, 70 \mathrm{~s}$, and $80 \mathrm{~s}$ were $2.9 \%, 10.3 \%$, $13.2 \%$, and $25.0 \%$ for men, and $2.1 \%, 9.1 \%, 20.5 \%$, and $54.2 \%$ for women, respectively. Prevalence in the present study was compared with that collected in 1990, showing improvements over time for men and women in their $50 \mathrm{~s}$, $60 \mathrm{~s}$, and $70 \mathrm{~s}$. Future problems with osteoporotic fractures in Japan might, thus, be less severe than previously predicted. Cumulative incidence over 10 years was detected by the number of incident cases divided by the number of all participants in the initial study. Incident cases were defined by two criteria. First, cases with prevalent VFx were excluded from both the numerators and the denominators. In this analysis, the cumulative incidence of the cases with first VFx was detected. Secondly, the cumulative incidence including the subjects who had suffered from the prevalent fractures and with an increased number of VFx in the following 10 years were calculated. This analysis clarified the cumulative incidence of cases with and without previous VFx. Incidence over 10 years of subjects in their $40 \mathrm{~s}, 50 \mathrm{~s}, 60 \mathrm{~s}$, and $70 \mathrm{~s}$ with first VFx were $2.2 \%, 4.9 \%$, $5.1 \%$, and $10.8 \%$ for men, and $2.1 \%, 4.5 \%, 14.0 \%$, and $22.2 \%$ for women, respectively. By contrast, if new cases were defined as including subjects who had suffered from previous fractures, but displayed an increased number of VFx, cumulative incidences for subjects in their $40 \mathrm{~s}, 50 \mathrm{~s}$, $60 \mathrm{~s}$, and $70 \mathrm{~s}$ were $2.1 \%, 8.3 \%, 10.0 \%$, and $12.2 \%$ for men, and $2.1 \%, 6.1 \%, 18.0 \%$, and $22.4 \%$ for women, respectively.

Keywords Cohort study - Cumulative incidence - Japanese · Prevalence $\cdot$ Vertebral fractures 


\section{Introduction}

Among fractures due to osteoporosis, vertebral fractures (VFx) are the most likely to lead to marked health problems. VFx are reportedly associated with functional impairment [1], back pain [2, 3], kyphosis [2, 3], esophageal reflux [4], depressive mood [5], respiratory dysfunctions [6], and decreased quality of life [7, 8]. In addition, VFx increase the risk of new VFx and hip fractures [9-13]. Furthermore, prevalent VFx reportedly increase mortality risk [14-16].

Although preventive strategies for VFx are urgently needed with the rapid aging of populations such as in Japan, little data is available concerning epidemiological characteristics in population samples, particularly in Japan [17-19]. A population-based cohort was established in 1990, comprising subjects aged 40- to 79-years-old from resident registrations for a village in a mountainous area, Miyama village, and follow-up studies were conducted in 1993, 1997, and 2000 [20-22]. In the previous report of the Miyama study, prevalences of VFx were ascertained for men and women [23].

In the present study, radiographic examination was performed on the same subjects after 10 years to assess secular trends of prevalence and to clarify cumulative incidences among different generations of VFx in a rural Japanese community.

\section{Participants and methods}

Epidemiological research based on populations has been conducted in Miyama village, Wakayama prefecture, Japan. As a detailed profile of the Miyama cohort has already been described elsewhere [20-23], a brief summary is provided here. In this village, a list of inhabitants aged 40- to 79years-old was compiled based on resident registrations as of the end of December 1988. As a result, a cohort of 1,543 inhabitants (716 men, 827 women) was identified. A selfadministered questionnaire survey regarding 125 daily activities such as smoking habits, alcohol consumption, and physical exercise was performed (baseline study).

From the above-mentioned cohort, 50 men and 50 women in each decade of age between 40 and 79 years (for a total of 400 participants) was recruited based on resident registrations for the purpose of measuring bone mineral density (BMD) in 1990 (initial BMD survey). In addition to BMD measurements using dual energy X-ray absorptiometry (DXA; Lunar DPX, GE Medical Systems, Madison, WI, USA), an interviewer-administered questionnaire, medical examination, and physical measurements were also performed for these participants. The questionnaire comprised 70 items, such as past history, history of medication, smoking habits, alcohol consumption, calcium intake, physical exercise, history of childbirth, history of lactation, and menstrual status. Radiographic examination of the spine was performed on all participants in 1990. Anteroposterior and lateral images of thoracolumbar vertebrae Th5-L5 were used for diagnosis (initial X-ray survey). Radiographic examination was again performed on subjects who provided consent after 10 years. Lateral images of thoracolumbar vertebrae Th5-L5 were again used for diagnosis (2nd X-ray survey).

Lateral spinal radiographs were examined for the presence of one or more VFx between Th5-L5, using the criteria defined by the Japan Bone and Mineral Society (Fig. 1) [24]. According to these criteria, the measurement of anterior, middle, and posterior heights on lateral radiography of the thoracic and lumbar spine is required, in order to determine ratios defining the anterior wedge, biconcave, and compound dimensions of the vertebral bodies. Diagnosis of VFx on all radiographs was performed by the same experienced orthopedic doctor (HK).

Prevalence and cumulative incidence were calculated by utilizing the results of diagnosis. Cumulative incidence is defined simply as the ratio of incident cases to the at-risk population at the beginning of the observation period. In the present study, cumulative incidence over 10 years was, thus, detected as the number of incident cases divided by the number of all participants in the initial study. Incident cases were defined using two criteria. First, cases with previous VFx were excluded from both numerators and denominators. In this analysis, the cumulative incidence of cases with first VFx was detected. Secondly, the cumulative incidence including subjects who had suffered from previous VFx but who displayed an increased number of VFx over the following 10 years was calculated. This analysis clarified the cumulative incidence of cases with and without previous VFx.

In the above-mentioned formula to obtain the cumulative incidence, the denominator was defined as the total number of participants in the initial X-ray survey. Using this definition, drop-outs during the observed 10 years were considered as non-VFx. To avoid underestimation caused wedge $\quad a / c<=75 \%$

fish

plate

$$
\begin{aligned}
& \text { a'/a and b'/b } \\
& \text { and } c^{\prime} / c<=80 \%
\end{aligned}
$$

a
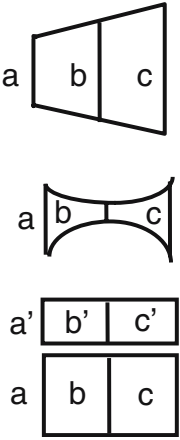

Fig. 1 Diagnostic criteria for vertebral fractures in Japan 
by the inclusion of drop-outs, another cumulative incidence was calculated by excluding drop-outs during the study period from the denominator. This index was defined as the cumulative incidence among survivors.

All statistical analyses were performed using STATA statistical software (STATA Corp., College Station, TX, USA).

\section{Results}

We note our findings as follows:

1. Eligible participants

Among 400 participants of the initial BMD examination, 390 provided consent to participate in the radiographic examination (194 men, 196 women; 97.5\%) of the initial survey. Radiographic evaluation after 10 years was completed for 287 of the 400 participants (132 men, 155 women; $71.8 \%$ ). The loss of 101 participants was explained as follows: 55 participants died (37 men, 18 women); 16 participants moved ( 8 men, 8 women); 13 participants were ill ( 4 men, 9 women); 8 participants were busy ( 8 men); 5 participants refused to participate further ( 5 men); and 4 participants were away from the area at the time of follow-up ( 1 man, 3 women). Another 12 participants ( 5 men, 7 women) were excluded from analysis due to the poor quality of radiographic images. Table 1 shows the physical characteristics of the remaining participants at the time of the initial X-ray survey.

2. Prevalence of VFx at the survey in 2000 and secular trends 1990-2000

The prevalences of VFx at follow-up in 2000 were calculated. The prevalences of VFx for subjects in their $50 \mathrm{~s}, 60 \mathrm{~s}, 70 \mathrm{~s}$, and $80 \mathrm{~s}$ were $2.9 \%, 10.3 \%, 13.2 \%$, and $25.0 \%$ for men, and $2.1 \%, 9.1 \%, 20.5 \%$, and $54.2 \%$ for women, respectively.

Figure 2 shows a comparison of VFx prevalences in the same age group according to the results of radiographic examination in 1990. The prevalences were significantly decreased between the 50 s to 70 s age groups in 2000 compared to $1990(P<0.05)$ (Fig. 2).

3. Cumulative incidence of VFx

The cumulative incidences over 10 years for men and women sorted by the presence or absence of VFx at the

Table 1 Characteristics of participants of the initial survey, classified by sex and age stratum

\begin{tabular}{|c|c|c|c|c|c|c|c|c|c|}
\hline \multirow[b]{2}{*}{ Birth cohort } & \multirow{2}{*}{$\begin{array}{l}\text { Age strata of } \\
\text { participants } \\
\text { Initial survey } \\
1990\end{array}$} & \multirow{2}{*}{$\begin{array}{l}\text { No. of } \\
\text { participants } \\
\text { Initial X-ray } \\
\text { survey } 1990\end{array}$} & \multirow{2}{*}{$\begin{array}{l}\text { No. of } \\
\text { participants } \\
\text { Follow-up } \\
2000\end{array}$} & \multicolumn{4}{|c|}{$\begin{array}{l}\text { Anthropometric measurements at the initial } \\
\text { survey (mean (SD)) }\end{array}$} & \multicolumn{2}{|c|}{$\begin{array}{l}\text { BMD measurements } \\
\text { on initial survey } \\
(\text { mean }(\mathrm{SD}))\end{array}$} \\
\hline & & & & $\begin{array}{l}\text { Age } \\
(\mathrm{yrs})\end{array}$ & $\begin{array}{l}\text { Height } \\
(\mathrm{cm})\end{array}$ & $\begin{array}{l}\text { Weight } \\
(\mathrm{kg})\end{array}$ & $\begin{array}{l}\text { BMI } \\
\left(\mathrm{kg} / \mathrm{m}^{2}\right)\end{array}$ & $\begin{array}{l}\text { BMD } \\
(\mathrm{L} 2-4)\end{array}$ & $\begin{array}{l}\text { BMD } \\
\text { (femoral } \\
\text { neck) }\end{array}$ \\
\hline Men & Total & 194 & 132 & $\begin{array}{l}56.9 \\
(10.3)\end{array}$ & $\begin{array}{r}161.3 \\
(6.7)\end{array}$ & $\begin{array}{l}58.2 \\
(9.2)\end{array}$ & $\begin{array}{l}22.3 \\
(2.5)\end{array}$ & $\begin{array}{l}1.10 \\
(0.19)\end{array}$ & $\begin{array}{l}0.88 \\
(0.14)\end{array}$ \\
\hline $1940-49$ & $40-49$ & 47 & 35 & $\begin{array}{l}44.1 \\
(3.2)\end{array}$ & $\begin{array}{r}166.3 \\
(5.8)\end{array}$ & $\begin{array}{l}63.8 \\
(8.4)\end{array}$ & $\begin{array}{l}23.0 \\
(2.3)\end{array}$ & $\begin{array}{l}1.18 \\
(0.17)\end{array}$ & $\begin{array}{l}0.97 \\
(0.15)\end{array}$ \\
\hline $1930-39$ & $50-59$ & 48 & 39 & $\begin{array}{l}53.9 \\
(2.6)^{\mathrm{a}}\end{array}$ & $\begin{array}{l}162.0 \\
(5.8)^{\mathrm{a}}\end{array}$ & $\begin{array}{c}60.1 \\
(8.2)\end{array}$ & $\begin{array}{l}22.8 \\
(2.4)\end{array}$ & $\begin{array}{l}1.16 \\
(0.18)\end{array}$ & $\begin{array}{l}0.91 \\
(0.12)\end{array}$ \\
\hline $1920-29$ & $60-69$ & 50 & 38 & $\begin{array}{l}63.2 \\
(2.8)^{\mathrm{ab}}\end{array}$ & $\begin{array}{l}159.4 \\
(5.4)^{\mathrm{a}}\end{array}$ & $\begin{array}{l}56.1 \\
(7.5)^{\mathrm{a}}\end{array}$ & $\begin{array}{l}22.0 \\
(2.4)\end{array}$ & $\begin{array}{l}1.03 \\
(0.19)^{\mathrm{ab}}\end{array}$ & $\begin{array}{l}0.82 \\
(0.12)^{\mathrm{ab}}\end{array}$ \\
\hline 1910-19 & $70-79$ & 49 & 20 & $\begin{array}{l}73.3 \\
(2.8)^{\mathrm{abc}}\end{array}$ & $\begin{array}{l}154.7 \\
(4.8)^{\mathrm{abc}}\end{array}$ & $\begin{array}{l}48.7 \\
(6.8)^{\mathrm{abc}}\end{array}$ & $\begin{array}{l}20.3 \\
(2.5)^{\mathrm{ab}}\end{array}$ & $\begin{array}{l}1.01 \\
(0.16)^{\mathrm{ab}}\end{array}$ & $\begin{array}{l}0.79 \\
(0.10)^{\mathrm{ab}}\end{array}$ \\
\hline Women & Total & 196 & 155 & $\begin{array}{l}56.7 \\
(10.1)\end{array}$ & $\begin{array}{r}149.0 \\
(6.0)\end{array}$ & $\begin{array}{l}49.7 \\
(8.1)\end{array}$ & $\begin{array}{l}22.3 \\
(2.8)\end{array}$ & $\begin{array}{l}0.98 \\
(0.23)\end{array}$ & $\begin{array}{l}0.76 \\
(0.14)\end{array}$ \\
\hline $1940-49$ & $40-49$ & 48 & 48 & $\begin{array}{l}44.6 \\
(3.0)\end{array}$ & $\begin{array}{r}152.6 \\
(4.7)\end{array}$ & $\begin{array}{c}53.6 \\
(8.3)\end{array}$ & $\begin{array}{c}22.9 \\
(2.8)\end{array}$ & $\begin{array}{l}1.18 \\
(0.16)\end{array}$ & $\begin{array}{l}0.88 \\
(0.12)\end{array}$ \\
\hline $1930-39$ & $50-59$ & 49 & 44 & $\begin{array}{l}54.8 \\
(2.7)^{\mathrm{a}}\end{array}$ & $\begin{array}{r}149.9 \\
(5.1)\end{array}$ & $\begin{array}{l}50.1 \\
(7.1)\end{array}$ & $\begin{array}{l}22.3 \\
(2.6)\end{array}$ & $\begin{array}{l}0.99 \\
(0.18)^{\mathrm{a}}\end{array}$ & $\begin{array}{l}0.75 \\
(0.12)^{\mathrm{a}}\end{array}$ \\
\hline $1920-29$ & $60-69$ & 50 & 39 & $\begin{array}{l}64.3 \\
(2.8)^{\mathrm{ab}}\end{array}$ & $\begin{array}{c}147.4 \\
(5.1)^{\mathrm{a}}\end{array}$ & $\begin{array}{l}47.5 \\
(6.9)^{\mathrm{a}}\end{array}$ & $\begin{array}{c}21.9 \\
(3.0)\end{array}$ & $\begin{array}{l}0.85 \\
(0.20)^{\mathrm{ab}}\end{array}$ & $\begin{array}{l}0.69 \\
(0.11)^{\mathrm{a}}\end{array}$ \\
\hline 1910-19 & $70-79$ & 49 & 24 & $\begin{array}{l}71.6 \\
(1.8)^{\mathrm{abc}}\end{array}$ & $\begin{array}{l}142.5 \\
(5.6)^{\mathrm{abc}}\end{array}$ & $\begin{array}{l}44.5 \\
(7.6)^{\mathrm{ab}}\end{array}$ & $\begin{array}{l}21.9 \\
(3.0)\end{array}$ & $\begin{array}{l}0.78 \\
(0.16)^{\mathrm{ab}}\end{array}$ & $\begin{array}{l}0.64 \\
(0.09)^{\mathrm{ab}}\end{array}$ \\
\hline
\end{tabular}

${ }^{\text {a }}$ Significantly different from values of the birth cohort group born in 1940-49

${ }^{\mathrm{b}}$ Significantly different from values of the birth cohort group born in 1930-39

${ }^{\mathrm{c}}$ Significantly different from values of the birth cohort group born in 1920-29 


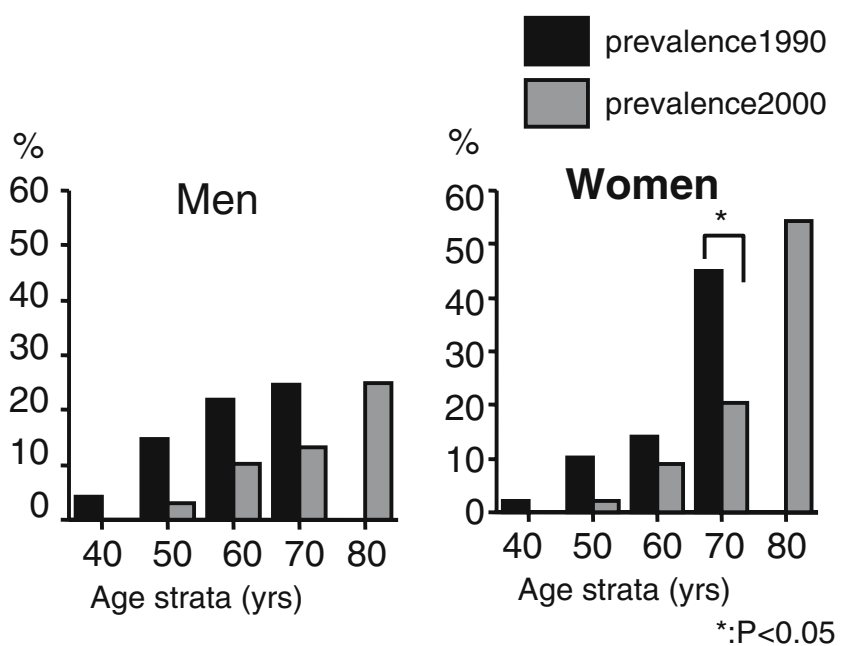

Fig. 2 Comparison of prevalence for vertebral fractures in the same age groups among participants in the X-ray examinations performed in 1990 and 2000

initial X-ray survey are shown in Table 2. The cumulative incidence of VFx including subjects with previous VFx after 10 years increased with age in both men and women.

After excluding cases with previous VFx, the cumulative incidence of first VFx for participants in their 40s, 50s, $60 \mathrm{~s}$, and 70 s increased with age in both men and women, and was higher in women than in men in all age strata, except the 40 s.

Although no association was identified between the cumulative incidence among participants with previous VFx and age in both men and women, cumulative incidence was significantly higher for subjects with previous VFx than for subjects without previous VFx in both men and women $(P<0.05)$.
4. Cumulative incidence of VFx among survivors

The cumulative incidences of VFx among cases with first VFx for survivors in their $40 \mathrm{~s}, 50 \mathrm{~s}, 60 \mathrm{~s}$, and $70 \mathrm{~s}$ were $2.9 \%, 2.8 \%, 8.6 \%$, and $21.1 \%$ for men, and $2.1 \%$, $7.0 \%, 18.9 \%$, and $31.3 \%$ for women, respectively. The cumulative incidence of the first VFx among survivors increased with age in both men and women, and was higher in women than in men in all age strata, except in the 40 s.

The cumulative incidences of VFx including subjects who had suffered from previous fractures or with increased numbers of VFx after 10 years for survivors in their $40 \mathrm{~s}, 50 \mathrm{~s}, 60 \mathrm{~s}$, and $70 \mathrm{~s}$ were $2.9 \%, 10.3 \%$, $13.2 \%$, and $30.0 \%$ for men, and $2.1 \%, 6.8 \%, 23.1 \%$, and $45.8 \%$ for women, respectively, suggesting an increase with age. Cumulative incidence was, again, significantly higher for subjects with previous VFx than for those without previous VFx in both men and women $(P<0.01)$.

\section{Discussion}

The present study evaluated the prevalence and cumulative incidence of VFx over 10 years using radiographic diagnosis after the performance of two radiographic examinations of the thoracolumbar spine in anteroposterior and lateral views of population-based subjects.

Compared with hip fractures, epidemiological studies of VFx have been less available. One reason for this is the fact that VFx are not always symptomatic, and longitudinal

Table 2 Cumulative incidences over 10 years for men and women classified by the presence or absence of VFx at the initial survey

\begin{tabular}{|c|c|c|c|c|c|c|c|c|c|c|}
\hline \multirow[b]{2}{*}{ Birth cohort } & \multirow[b]{2}{*}{$\begin{array}{l}\text { Age } \\
\text { strata at } \\
\text { the initial } \\
\text { survey } \\
\text { (yrs) }\end{array}$} & \multicolumn{3}{|c|}{ All participants } & \multicolumn{3}{|c|}{$\begin{array}{l}\text { With presence of VFx at the initial } \\
\text { survey }\end{array}$} & \multicolumn{3}{|c|}{$\begin{array}{l}\text { With absence of VFx at the initial } \\
\text { survey }\end{array}$} \\
\hline & & $\begin{array}{l}\text { No. of } \\
\text { new } \\
\text { VFx } \\
1990- \\
2000\end{array}$ & $\begin{array}{l}\text { No. of } \\
\text { participants } \\
\text { initial X-ray } \\
\text { survey } 1990\end{array}$ & $\begin{array}{l}\text { Cumulative } \\
\text { incidence } \\
(\%)\end{array}$ & $\begin{array}{l}\text { No. of } \\
\text { new VFx } \\
\text { cases } \\
1990- \\
2000\end{array}$ & $\begin{array}{l}\text { No. of } \\
\text { participants } \\
\text { initial } \\
\text { survey } \\
1990\end{array}$ & $\begin{array}{l}\text { Cumulative } \\
\text { incidence } \\
(\%)\end{array}$ & $\begin{array}{l}\text { No. of } \\
\text { new VFx } \\
\text { cases } \\
1990- \\
2000\end{array}$ & $\begin{array}{l}\text { No. of } \\
\text { participants } \\
\text { initial } \\
\text { survey } \\
1990\end{array}$ & $\begin{array}{l}\text { Cumulative } \\
\text { incidence } \\
(\%)\end{array}$ \\
\hline Men & Total & 16 & 194 & 8.2 & 7 & 32 & 21.9 & 9 & 162 & 5.6 \\
\hline $1940-49$ & $40-49$ & 1 & 47 & 2.1 & 0 & 2 & 0.0 & 1 & 45 & 2.2 \\
\hline $1930-39$ & $50-59$ & 4 & 48 & 8.3 & 2 & 7 & 28.6 & 2 & 41 & 4.9 \\
\hline $1920-29$ & $60-69$ & 5 & 50 & 10.0 & 3 & 11 & 27.3 & 2 & 39 & 5.1 \\
\hline 1910-19 & $70-79$ & 6 & 49 & 12.2 & 2 & 12 & 16.7 & 4 & 37 & 10.8 \\
\hline Women & Total & 24 & 196 & 12.2 & 9 & 35 & 25.7 & 16 & 161 & 9.9 \\
\hline $1940-49$ & $40-49$ & 1 & 48 & 2.1 & 0 & 1 & 0.0 & 1 & 47 & 2.1 \\
\hline $1930-39$ & $50-59$ & 3 & 49 & 6.1 & 1 & 5 & 20.0 & 2 & 44 & 4.5 \\
\hline $1920-29$ & $60-69$ & 9 & 50 & 18.0 & 3 & 7 & 42.9 & 6 & 43 & 14.0 \\
\hline 1910-19 & $70-79$ & 11 & 49 & 22.4 & 5 & 22 & 22.7 & 6 & 27 & 22.2 \\
\hline
\end{tabular}


population surveys are required to clarify epidemiological indices. The present study used subjects representative of the whole town, and careful follow-up was performed. One limitation was the use of a relatively small number of fractures and small study population to determine the prevalence and cumulative incidence of VFx. However, few such longitudinal observational studies with high participation rates have been reported, representing the principal strength of this study.

Another reason for the scarcity of data on this subject is the lack consensus regarding the definition of VFx [25]. The present study utilized the diagnostic criteria of the Japan Bone and Mineral Society, as these criteria are the most popular and most commonly used in various clinical fields in Japan. These criteria seem to use the kind of semiquantative (SQ) method advocated by Genant et al. [26]. From the perspective of grading in SQ methods, the criteria of the Japan Bone and Mineral Society correspond to grades above SD2. The epidemiological indices in the present study, thus, did not include cases classifiable as SD1, suggesting that the results obtained using Japanese criteria might represent an underestimation compared to other results diagnosed using SQ methods.

Population-based prevalence studies of VFx have been performed in Western countries, such as the USA [27], Denmark [28, 29], Finland [30], Sweden [31, 32], the Netherlands [33], England [34, 35], and France [36, 37], and in a multicenter study involving 19 European countries [38]. In Asia, the prevalence of VFx has been reported in Taiwan [39], China [40], and Japan [18, 19, 24]. Cummings et al. compared the results of population-based studies of radiological VFx prevalence in women $\geq 50$-years-old between Europe, Minnesota (USA), Hawaii (USA), Hiroshima (Japan), Taiwan, and Beijing (China) [41]. In this comparison, the prevalence of VFx among women $>70$-years-old was higher in Japan than in the USA or China, and was as high as that in Europe. The prevalence of VFx in the mountainous area of the present study was much higher than that in Hiroshima, an urban area, suggesting that regional differences in VFx might be present in Japan.

The present study clarified differences in the prevalence of VFx for given age strata between birth cohorts. The comparison of data collected in 1990 and 2000 showed improvements over time for men and women in their 50s, $60 \mathrm{~s}$, and $70 \mathrm{~s}$. A previous report has already noted that BMD data from 1990 and 2000 showed significant improvements for men in their $60 \mathrm{~s}$ and for women in their 50s [23], concluding that this might predict a decrease in the prevalence of osteoporosis in the near future in Japan. The present results suggest that the prevalence of not only osteoporosis, but also osteoporotic fractures, could decrease in the future in Japan. Fujiwara et al. assessed the effects of birth cohort on the incidence of VFx in Hiroshima, and reported that incidence decreased by a factor of 0.5 in men and 0.6 in women with each succeeding birth decade [17]. The present data are consistent with these findings.

This low prevalence of VFx in more recent birth cohorts may reflect nutritional improvements, in addition to BMD improvements. As noted elsewhere [23], nationwide nutritional surveys have reported the mean calcium intake as $253 \mathrm{mg}$ /day in 1946 (1st survey), $338 \mathrm{mg} /$ day in 1955, $465 \mathrm{mg} /$ day in 1965 , and $552 \mathrm{mg}$ /day in 1975 [42], representing a dramatic increase. These nutritional improvements might be expected to increase body build and BMD, and, thus, decrease the prevalence of VFx in all age groups. Another possible reason for the decreasing prevalence of VFx might be the effects of action taken for the prevention of osteoporosis by the government and academic societies. To achieve the prevention of osteoporosis, the Ministry of Health, Labour and Welfare recommended all that communities start BMD screening for middle-aged and elderly female residents in 1995. These examinations in various communities have enabled many women to become more aware of osteoporosis. Moreover, the Japan Osteoporosis Foundation and the Japan Osteoporosis Society, which were established in 1991 and 1999, respectively, have been conducting public education campaigns to inform the general population about osteoporosis and risk factors. These efforts by both the government and academic societies might have resulted in the decreasing prevalence of VFx.

Regarding the incidence of VFx, while some epidemiological studies have been reported from Western countries [43-45], the only investigation from Japan was reported by Fujiwara et al. [18]. Fujiwara et al. performed radiographic examinations in 1994-1995, with follow-up at an average of 4 years, and clarified the incidence of VFx in their Hiroshima cohort. Incidences of VFx in this Hiroshima cohort increased with age, particularly after about 60 years of age, and women displayed a nearly two-fold greater incidence of VFx than men. The incidence of VFx was much higher in individuals with previous VFx than in those without previous VFx. As cumulative incidence was clarified in the present study, rather than incidence, direct comparison of the present results with those of Fujiwara et al. might be incorrect. However, findings in the present study, such as age-dependency, sex differences, and higher incidence in individuals with previous VFx than in those without previous VFx, are consistent with the results of the previous investigation in Hiroshima.

The cumulative incidence for participants at the initial survey in the present study could be considered as a 10-year probability according to age. In this mountain village, $12.2 \%$ of men and $22.4 \%$ of women in their 70 s will suffer new morphometric VFx in the next 10 years. Kanis et al. reported the 10-year probability of clinical VFx in female 
participants in the European Prospective Osteoporosis Study [46]. The 10-year probability of clinical VFx among women with a $0 \mathrm{Z}$-score of amplitude-dependent speed of sound on quantitative ultrasound (QUS) measurements was $3.9 \%$ at 70 years old, $4.5 \%$ at 75 years old, and $4.9 \%$ at 80 years old. Although only about one-third of morphometric fractures reportedly come to medical attention [43], the present results indicated much higher incidences than those described by Kanis et al. Although the future incidence of VFx in the Japanese population could be predicted to decrease, elderly individuals seem to remain at high risk. To reduce the incidence and prevalence of osteoporosis and osteoporotic fractures, further epidemiological research is needed to facilitate the development of affordable strategies for the early identification of high-risk individuals.

Acknowledgments This work was supported by Grants-in-Aid for Scientific Research C16590512 from the Ministry of Education, Science, Sports, and Culture in Japan, H16-Chihou Kossetsu-021, H17-Meneki-009 from the Ministry of Health, Labour and Welfare, and the grant from the Japan Osteoporosis Society.

\section{References}

1. Burger H, Van Daele PL, Grashuis K, Hofman A, Grobbee DE, Schutte HE, Birkenhanger JC, Pols HA (1977) Vertebral deformities and functional impairment in men and women. $\mathrm{J}$ Bone Miner Res 12(1):152-157

2. Ross PD (1977) Clinical consequences of vertebral fractures. Am J Med 103(2A):30S-43S

3. Nevitt MC, Ettinger B, Black DM, Stone K, Jamal SA, Ensrud K, Segal M, Genant HK, Cummings RS (1988) The association of radiographically detected vertebral fractures with back pain and function: a prospective study. Ann Intern Med 128(10):793-800

4. Yamaguchi T, Sugimoto T, Yamada H, Kanzawa M, Yano S, Yamauchi M, Chihara K (2002) The presence and severity of vertebral fractures is associated with the presence of esophageal hiatal hernia in postmenopausal women. Osteoporos Int 13(4):331-336

5. Gold DT, Lyles KW, Shipp KM, Drezner MK (2001) Osteoporosis and its nonskeletal consequences: their impact on treatment decisions. In: Marcus R, Feldman D, Kelsey J (eds) Osteoporosis, 2nd edn. Academic Press, San Diego, California, pp 819-829

6. Leech JA, Dulberg C, Kellie S, Pattee L, Gay J (1990) Relationship of lung function to severity of osteoporosis in women. Am Rev Respir Dis 141(1):68-71

7. Gold DT (1966) The clinical impact of vertebral fractures: quality of life in women with osteoporosis. Bone 18(3 Suppl):185S-189S

8. Oleksik A, Lips P, Dawson A, Minshall ME, Shen W, Cooper C, Kanis J (2000) Health-related quality of life in postmenopausal women with low BMD with or without prevalent vertebral fractures. J Bone Miner Res 15(7):1384-1392

9. Ross PD, Davis JW, Epstein RS, Wasnich RD (1991) Pre-existing fractures and bone mass predict vertebral fracture incidence in women. Ann Intern Med 114(11):919-923

10. Ross PD, Genant HK, Davis JW, Miller PD, Wasnich RD (1993) Predicting vertebral fracture incidence from prevalent fractures and bone density among non-black, osteoporotic women. Osteoporos Int 3(3):120-126
11. Nevitt MC, Ross PD, Palermo L, Musliner T, Genant HK, Thompson DE (1999) Association of prevalent vertebral fractures, bone density, and alendronate treatment with incident vertebral fractures: effect of number and spinal location of fractures. The Fracture Intervention Trial Research Group. Bone 25(5):613-619

12. Black DM, Arden NK, Palermo L, Pearson J, Cummings SR (1999) Prevalent vertebral deformities predict hip fractures and new vertebral deformities but not wrist fractures. Study of Osteoporotic Fractures Research Group. J Bone Miner Res 14 (5):821-828

13. Burger H, van Daele PLA, Algra D, Hofman A, Grobbee DE, Schutte HE, Birkenhager JC, Pols HA (1994) Vertebral deformities as predictors of non-vertebral fractures. BMJ 309:991-992

14. Center JR, Nguyen TV, Schneider D, Sambrook PN, Eisman JA (1999) Mortality after all major types of osteoporotic fracture in men and women: an observational study. Lancet 353(9156):878-882

15. Ensrud KE, Thompson DE, Cauly JA, Nevitt MC, Kado DM, Hochberg MC, Santora AC 2nd, Black DM (2000) Prevalent vertebral deformities predict mortality and hospitalization in older women with low bone mass. Fracture Intervention Trial Research Group. J Am Geriatr Soc 48(3):241-249

16. Johnell O, Kanis JA, Oden A, Sernbo I, Redlund-Johnell I, Petterson C, De Laet C, Jonsson B (2004) Mortality after osteoporotic fractures. Osteoporos Int 15(1):38-42

17. Fujiwara S, Mizuno S, Ochi Y, Sasaki H, Kodama K, Russell WJ, Hosoda Y (1991) The incidence of thoracic vertebral fractures in a Japanese population, Hiroshima and Nagasaki, 1958-1986. J Clin Epidemiol 44(10):1007-1014

18. Fujiwara S, Kasagi F, Masunari N, Naito K, Suzuki G, Fukunaga M (2003) Fracture prediction from bone mineral density in Japanese men and women. J Bone Miner Res 18(8):1547-1553

19. Kitazawa A, Kushida K, Yamazaki K, Inoue T (2001) Prevalence of vertebral fractures in a population-based sample in Japan. J Bone Miner Metab 19(2):115-118

20. Kasamatsu T, Morioka S, Hashimoto T, Kinoshita H, Yamada H, Tamaki T (1991) Epidemiological study on the bone mineral density of inhabitants in Miyama Village, Wakayama prefecture (Part I). Background of study population and sampling method. J Bone Miner Metab 9(Suppl 1):50-55

21. Kinoshita H, Danjoh S, Yamada H, Tamaki T, Kasamatsu T, Ueda A, Hashimoto T (1991) Epidemiological study on the bone mineral density of inhabitants in Miyama Village, Wakayama prefecture (part II). Bone mineral density of the spine and proximal femur. J Bone Miner Metab 9(Suppl 1):56-60

22. Yoshimura N, Kinoshita H, Danjoh S, Takijiri T, Morioka S, Kasamatsu T, Sakata K, Hashimoto T (2002) Bone loss at the lumbar spine and the proximal femur in a rural Japanese community, 1990-2000: the Miyama study. Osteoporos Int 13 (10):803-808

23. Yoshimura N, Kinoshita H, Danjoh S, Yamada H, Tamaki T, Morioka S, Kasamatsu T, Hashimoto T, Inoue T (1995) Prevalence of vertebral fractures in a rural Japanese population. J Epidemiol 5:171-175

24. Inoue $\mathrm{T}$ (1990) Clinical features and findings, osteoporosis (in Japanese). Bone 4:39-47

25. National Osteoporosis Foundation Working Group on Vertebral Fractures (1995) Report assessing vertebral fractures. J Bone Miner Res 10:518-523

26. Genant HK, Wu CY, Van Kujuk C, Nivitt MC (1993) Vertebral fracture assessment using a semiquantative technique. J Bone Miner Res 8:1137-1148

27. Ross PD, Fujiwara S, Huang C, Davis JW, Epstein RS, Wasnich RD, Kodama K, Melton LJ 3rd (1995) Vertebral fracture prevalence in women in Hiroshima compared to Caucasians or Japanese in the US. Int J Epidemiol 24(6):1171-1177 
28. Hansen MA, Overgaard, Nielsen VAH, Jensen GF, Gotfredsen A, Christiansen C (1992) No secular increase in the prevalence of vertebral fractures due to postmenopausal osteoporosis. Osteoporos Int 2(5):241-246

29. Jensen GF, Christiansen C, Boesen J, Hegedus V, Transbol I (1982) Epidemiology of postmenopausal spinal and long bone fractures: a unifying approach to postmenopausal osteoporosis. Clin Orthop 166:75-81

30. Harna M, Heliovaara M, Aromaa A, Knekt P (1986) Thoracic spine compression fractures in Finland. Clin Orthop 205:188-194

31. Bengner UU, Johnell O, Redlund-Johnell I (1988) Changes in incidence and prevalence of vertebral fractures during 30 years. Calcif Tissue Int 42(5):293-296

32. Hasserius R, Redlund-Johnell I, Mellstrom D, Johansson C, Nilsson BE, Johnell O (2001) Vertebral deformation in urban Swedish men and women: prevalence based on 797 subjects. Acta Orthop Scand 72(3):273-278

33. Pluijm SMF, Tromp AM, Smit JH, Deeg DJH, Lips P (2000) Consequences of vertebral deformities in older men and women. J Bone Miner Res 15(8):1564-1572

34. Cooper C, Shah S, Hand DJ, Adams J, Compston J, Davie M, Woolf A (1991) Screening for vertebral osteoporosis using individual risk factors. The Multicentre Vertebral Fracture Study Group. Osteoporos Int 2(1):48-53

35. Spector TD, McCloskey EV, Dogle DV, Kanis JA (1993) Prevalence of vertebral fracture in women and the relationship with bone density and symptoms: the Chingford Study. J Bone Miner Res 8(7):817-822

36. Szulc P, Marchand F, Felsenberg D, Delmas PD (1998) Prevalence of vertebral deformities according to the diagnostic method. Rev Rhum Engl Ed 65(4):245-256

37. Grados F, Marcelli C, Dargent-Molina P, Roux C, Vergnol JF, Meunier PJ, Fardellone P (2004) Prevalence of vertebral fractures in French women older than 75 years from the EPIDOS study. Bone 34(2):362-367
38. O’Neill TW, Felsenberg D, Varlow J, Cooper C, Kanis JA, Silman AJ (1996) The prevalence of vertebral deformity in European men and women: the European Vertebral Osteoporosis Study. J Bone Miner Res 11(7):1010-1018

39. Tsai K, Twu S, Chieng P, Yang R, Lee T (1996) Prevalence of vertebral fractures in Chinese men and women in urban Taiwanese communities. Calcif Tissue Int 59(4):249-253

40. Ling X, Cummings SR, Mingwei Q, Xihe Z, Xioashu C, Nevitt M, Stone K (2000) Vertebral fractures in Beijing, China: the Beijing Osteoporosis Project. J Bone Miner Res 15 (10):2019-2025

41. Cummings SR, Melton KJ 3rd (2002) Epidemiology and outcomes of osteoporotic fractures. Lancet 359(9319):1761-1767

42. Office for Lifestyle-Related Diseases Control, Health Services Bureau, Ministry of Health, Labour and Welfare (1998) The trend of dietary circumstances after World War II. Annual report of the national nutrition survey, Japan (in Japanese). Daiichi Shuppan, Tokyo, Japan, pp 145-150

43. Cooper C, Aekinson EJ, O'Fallon WM, Melton LJ 3rd (1992) Incidence of clinically diagnosed vertebral fractures: a populationbased study in Rochester, Minnesota, 1985-1989. J Bone Miner Res 7(2):449-456

44. Sanders KM, Pasco JA, Ugoni AM, Nicholson GC, Seeman E, Martin TJ, Skoric B, Panahi S, Kotowicz MA (1998) The exclusion of high trauma fractures may underestimate the prevalence of bone fragility fractures in the community: the Geelong Osteoporosis Study. J Bone Miner Res 13(8):1337-1342

45. The European Prospective Osteoporosis Study Group (2002) Incidence of vertebral fracture in Europe: results from the European Prospective Osteoporosis Study (EPOS). J Bone Miner Res 17(4):716-724

46. Kanis JA, Johnell O, Oden A, De Laet C, De Terlizzi F (2005) Ten-year probabilities of clinical vertebral fractures according to phalangeal quantitative ultrasonography. Osteoporos Int 16 (9):1065-1070 